\title{
Efektivitas Antidiabetes Fraksi Air Daun Karamunting (Rhodomyrtus Tomentosa (Ait.) Hassk.) terhadap Kadar Glukosa Darah dan Sekresi Insulin pada Tikus Model Diabetes
}

\author{
Geri Febriyanto $^{1^{*}}$, Mgs. Irsan Saleh ${ }^{2}$, Theodorus ${ }^{3}$ \\ Program Studi Ilmu Biomedik, Fakultas Kedokteran, Universitas Sriwijaya, Sumatera \\ Selatan, Indonesia ${ }^{1}$ \\ Departemen Farmakologi Fakultas Kedokteran, Universitas Sriwijaya, Sumatera \\ Selatan, Indonesia ${ }^{2}$ \\ Departemen Farmakologi Fakultas Kedokteran, Universitas Sriwijaya, Sumatera \\ Selatan, Indonesia ${ }^{3}$ \\ *e-mail: geri.febriyan11@gmail.com
}

\begin{abstract}
Abstrak
Penelitian ini bertujuan untuk mengetahui efektivitas fraksi air daun karamunting (Rhodomyrtus tomentosa (Ait.) Hassk). Terhadap penurunan kadar glukosa darah 2 jam post prandial dan peningkatan kadar insulin tikus putih jantan yang diinduksi streptozotocin. Penelitian ini merupakan penelitian experimental laboratorik in vivo. Subjek penelitian ini berupa tikus putih jantan berjumlah 30 ekor yang dibagi dalam 5 kelompok yaitu kontrol positif menggunakan glibenclamide, Kontrol negatif menggunakan $\mathrm{Na} C \mathrm{CMC}$, kelompok perlakuan menggunakan fraksi air daun karamunting $70 \mathrm{mg} / \mathrm{KgBB}, 140 \mathrm{mg} / \mathrm{KgBB}$, dan $280 \mathrm{mg} / \mathrm{KgBB}$. Hasil penelitian menunjukkan bahwa kelompok fraksi air daun karamunting $70 \mathrm{mg} / \mathrm{KgBB}$. $140 \mathrm{mg} / \mathrm{KgBB}$, dan $280 \mathrm{mg} / \mathrm{KgBB}$ efektif menurunkan kadar glukosa darah 2 jam pos prandial dan meningkatkan kadar insulin. Berdasarkan hasil yang diperoleh dapat disimpulkan bahwa fraksi air daun karamunting (Rhodomyrtus tomentosa (Ait.) Hassk). Efektif menurunkan kadar glukosa darah 2 jam post prandial dan meningkatkan kadar insulin dengan dosis $280 \mathrm{mg} / \mathrm{KgBB}$ merupakan dosis yang paling efektif.
\end{abstract}

Kata Kunci: Rhodomyrtus tomentosa (Ait.) Hassk, Karamunting, Diabetes Mellitus, in vivo

\section{Antidiabetic Efficacy of Karamunting (Rhodomyrtus tomentosa (Ait.)Hassk) Leaf Water Fraction on Blood Glucose and Insulin Secretion in Diabetic Mouse Models}

\begin{abstract}
This study aims to determine the effectiveness of the water fraction of caramunting leaves (Rhodomyrtus tomentosa (Ait.) Hassk). Against a decrease in blood glucose levels 2 hours post prandial and an increase in insulin levels of male white rats induced by streptozotocin. This research is an in vivo laboratory experimental research. The subjects of this study were 30 male white rats divided into 5 groups, namely positive control using glibenclamide, negative control using $\mathrm{Na} C \mathrm{CMC}$, treatment group using caramunting leaf water fraction $70 \mathrm{mg} / \mathrm{KgBB}, 140 \mathrm{mg} /$ $\mathrm{KgBB}$, and $280 \mathrm{mg} / \mathrm{KgBB}$. The results showed that the caramunting leaf water fraction group was $70 \mathrm{mg} / \mathrm{KgBB} .140 \mathrm{mg} / \mathrm{KgBB}$, and $280 \mathrm{~m} / \mathrm{KgBB}$ effectively reduce blood glucose levels 2 hours post prandial and increase insulin levels. Based on the results obtained, it can be concluded that
\end{abstract}


Efektivitas Antidiabetes Fraksi Air Daun Karamunting (Rhodomyrtus Tomentosa (Ait.) Hassk.)... Geri Febriyanto, Mgs. Irsan Saleh, Theodorus

the water fraction of caramunting leaves (Rhodomyrtus tomentosa (Ait.) Hassk). Effectively reducing blood glucose levels 2 hours post prandial and increasing insulin levels with a dose of $280 \mathrm{mg} / \mathrm{KgBB}$ is the most effective dose.

Keywords: Rhodomyrtus tomentosa (Ait.) Hassk, Karamunting, Diabetes Mellitus, in vivo

\section{PENDAHULUAN}

Diabetes merupakan kondisi kronis yang terjadi ketika kadar glukosa darah di atas batas normal. Ini terjadi jika pankreas tidak menghasilkan cukup insulin (hormon yang mengatur gula darah) atau ketika tubuh tidak dapat secara efektif menggunakan insulin yang dihasilkannya (WHO, 2012). Meningkatnya kadar glukosa dalam darah (hiperglikemia) jika dibiarkan dalam jangka panjang, dapat menyebabkan kerusakan pada berbagai organ tubuh, yang mengarah pada pengembangan komplikasi kesehatan yang melumpuhkan dan mengancam jiwa seperti penyakit kardiovaskular, neuropati, nefropati dan penyakit mata, yang menyebabkan retinopati dan kebutaan. Di sisi lain, jika manajemen diabetes yang tepat tercapai, komplikasi serius ini dapat ditunda atau dicegah (IDF, 2017).

Pada penelitian terbaru tahun 2018 menunjukkan bahwa prevalensi DM berdasarkan pemeriksaan darah pada penduduk dengan umur $\geq 15$ tahun adalah 10,9 \% (Riskesdas, 2018).

World Health Organization (WHO) memprediksi kenaikan jumlah penyandang
DM di Indonesia dari 8,4 juta pada tahun 2000 menjadi sekitar 21,3 juta pada tahun 2030. International Diabetes Federation (IDF) memprediksi adanya kenaikan jumlah penyandang DM di Indonesia dari 9,1 juta pada tahun 2014 menjadi 14,1 juta pada tahun 2035. Berdasarkan data dari IDF 2014, Indonesia menempati peringkat ke-5 di dunia, atau naik dua peringkat dibandingkan dengan tahun 2013 dengan 7,6 juta orang penyandang DM (Decroli, 2019).

Sintesis dan sekresi insulin terjadi di dalam sel beta. Proses ini melibatkan beberapa komponen yang berperan dalam sintesis untuk menghasilkan insulin dan menyekresikannya ke luar sel. Pada keadaan tertentu komponen-komponen tersebut dapat mengalami disfungsi dan mengakibatkan terjadinya penyakit. Masalah yang dapat terjadi pada sintesis insulin antara lain: 1) ketidakmampuan pulau Langerhans untuk menghasilkan insulin dan 2) adanya stres pada RE yang melibatkan the un-folded protein response (UPR) (Banjarnahor, 2012). Kondisi DM dapat diinduksi pada hewan model dengan cara pemberian zat kimia sebagai induktor 
DM (diabetogen). Diabetogen yang sering digunakan pada hewan model antara lain alloxan dan streptozotocin. Streptozotocin bekerja dengan cara membentuk radikal bebas sangat reaktif yang dapat menimbulkan kerusakan pada membran sel, protein, dan deoxyribonucleic acid (DNA), sehingga menyebabkan gangguan produksi insulin oleh sel beta langerhans pankreas, berbeda dengan Alloxan, STZ memiliki waktu paruh yang cukup lama. Streptozotocin memasuki sel beta langerhans pankreas melalui glucose transporter 2 (GLUT 2) dan menyebabkan alkilasi (Szkudelski, 2001).

Terdapat beberapa klasifikasi Diabetes Mellitus sesuai dengan anjuran PERKENI dan American diabetes Association (ADA) antara lain, Diabetes mellitus tipe 1, Diabetes mellitus tipe 2, Diabetes Mellitus Gestasional, dan Diebetes Mellitus tipe lain yang dapat terjadi karena Defek genetic fungsi sel beta, defek genetik kerja insulin, penyakit endokrin pankreas, endokrinopati, infeksi, sebab imunoloi, serta karena obatobat atau zat kimia dan sindrom genetik (Shahab, 2017).

Karamunting

(Rhodomyrtus tomentosa (Ait.) Hssk.) merupakan tanaman yang tumbuh dengan panjang hingga 12 kaki, bunganya berwarna putih pucat, berdiameter 2,5-3 cm, dan setiap bunga memiliki 5 kelopak (Hamid, 2017).
Masyarakat Kalimantan dan Thailand Selatan menggunakan tanaman ini untuk mengobati berbagai macam penyakit seperti diabetes mellitus, diare, luka bakar, dan sakit perut (Hasibuan et al, 2015). Tumbuhan Karamunting ini mengandung senyawa triterpenoid/steroid, alkaloid, dan flavonoid, karbohidrat, dan saponin (Geetha et al, 2012). Senyawa alkaloid dan flavonoid adalah salah satu kandungan metabolit sekunder yang banyak digunakan sebagai obat, antara lain untuk mengobati gangguann kulit, diabetes, gangguann menstruasi, malaria dan antiinflamasi. Sedangkan triterpenoid/ steroid banyak digunakan sebagai bahan baku untuk pembuatan hormone steroid (Hasibuan et al, 2015). Kandungan metabolit sekunder yang berhasil diisolasi dari karamunting antara lain flavonoid combetrol, cyanidin 3galaktosa, quercetin, myricetin, dan lain sebagainya (Hamid, 2017) Hasil penelitian membuktikan bahwa ekstrak air daun karamutig pada dosis $100 \mathrm{mg} / \mathrm{kg}$ memberikan efek terbaik dalam menurukan kadar glukosa darah tikus diabetes yang diinduksi alloxan (Hasibuan et al, 2015). Sedangkan penelitian pada fraksi air daun karamunting terhadap mencit model diabetes yang diberikan secara oral dengan dosis 10, 20, dan $40 \mathrm{mg} / \mathrm{kgBB}$ menunjukkan adanya penurunan kadar glukosa darah secara bermakna $(P<0,005)$ dan dapat 
Efektivitas Antidiabetes Fraksi Air Daun Karamunting (Rhodomyrtus Tomentosa (Ait.) Hassk.)... Geri Febriyanto, Mgs. Irsan Saleh, Theodorus

memperbaiki berat badan serta volume urine mencit diabetes (Sinata, 2016).

Metabolit sekunder yang berupa flavonoid memiliki efek sebagai antidiabetik melalui fungsinya sebagai antioksidan, flavonoid dapat menggunnakan aktivitas antioksiadannya dengan mekanisme mengikat radikal bebas dan ion logam, atau dengan menghambat system enzimatik yang bertanggung jawab untuk pembentukan radikal bebas.

\section{BAHAN DAN METODE}

Penelitian ini berupa penelitian eksperimental laboratorik in vivo yang dilaksanakan di laboratorium bioteknologi dan animal house Fakultas Kedokteran Universitas Sriwijaya Palembang. Populasi dalam penelitian ini adalah tikus jantan strain Rattus. Sampel yang digunakan dalam penelitian ini sebanyak 30 tikus putih jantan yang dibagi dalam 5 kelompok.

\section{Alat}

Alat yang digunakan pada penelitian ini adalah: ELISA reader, ELISA kit Insulin Plasma, Gluco-DR, seperangkat alat Rotary evaporator, alat timbangan tikus, spuit, kapas, tissu, sarung tangan, masker, erlemeyer, dan beker glass.

Bahan

Bahan yang digunakan pada penelitian ini adalah:
- Daun karamunting (Rhodomyrtus tomentosa (Ait.) Hssk.) yang akan dibuat menjadi fraksi kental.

- Streptozotocin

- Glibencamide murni (Sigma Aldrich)

- Air suling

- Etanol 96\%

- $\mathrm{Na} \mathrm{CMC}$

\section{Prosedur Kerja}

Sebanyak $500 \mathrm{~g}$ daun karamunting Kering diekstraksi dengan metode maserasi menggunakan etanol. Kemudian ekstrak etanol daun karamunting hasil maserasi diuapkan menggunakan rotary evaporator. Maserat yang telah diuapkan di fraksinasi dengan $\mathrm{n}$-heksan dan air dalam corong pisah. Kocok secukupnya, kemudian sampel dibiarkan sampai terbentuk 2 lapisan yaitu lapisan n-heksan dan air. Lakukan sebanyak 3 kali. Kemudian lapisan air di fraksinasi dengan etil-asetat, lakukan sebanyak 3 kali sehingga di peroleh lapisan air dan etilasetat. Setelah itu, fraksi air kemudian diuapkan. Setelah itu fraksi air daun karamunting dikeringkan lagi menggunakan bantuan hair dryer sehingga diperoleh fraksi air yang kental berbentuk seperti pasta yang akan digunakan untuk perlakuan.

\section{Dosis Induksi Streptozotocin}

Pada penelitian ini untuk menginduksi hiperglikemia pada hewan coba digunakan Streptozotocin. STZ 
diinjeksikan dengan cara intraperitoneal. Dosis pemberian STZ sebanyak $45 \mathrm{mg} / \mathrm{kg} \mathrm{BB}$ berdasarkan penelitian sebelumnya (Saputra, 2018).

\section{Suspensi Glibenclamide}

Kontrol positif pada penelitian ini menggunakan glibenclamide sebagai obat pembanding dengan dosis $0,09 \mathrm{mg} / \mathrm{kgBB}$. Suspensi glibenclamid dibua dengan kandungan $\quad 0,1 \mathrm{mg} / \mathrm{ml}$. Suspensi glibenclamide dibuat dengan menimbang terlebih dahulu Glibenclamide sebanyak5 mg, kemudian Campurkan massa $\mathrm{Na}-\mathrm{CMC}$ 1\% kedalam massa glibenclamide sedikit demi sedikit, lalu gerus hingga homogen, setelah itu Pindahkan kedalam gelas ukur $50 \mathrm{ml}$ kemudian tambahkan aquadest sedikit demi sedikit sampai tanda dan dikocok/diaduk sampai homogen.

\section{Pembuatan Larutan Natrium Carboxy Methyl Cellulose (Na CMC) 1\%}

Cuci bersih dan kalibrasi botol $200 \mathrm{ml}$. Timbang $\mathrm{Na} \mathrm{CMC}$ sebanyak 2 gram, kemudian masukkan air hangat sebanyak 40 $\mathrm{ml}$ ke dalam mortar, lalu taburkan Na CMC di atas air hangat dan biarkan hingga mengembang. Setelah itu digerus hingga homogen lalu masukkan ke dalam botol dan tambahkan air sedikit demi sedikit kemudian di ad kan hingga $200 \mathrm{ml}$.

\section{Prosedur Perlakuan}

Tikus dipuasakan selama \pm 8 jam tetapi tetap diberi minum, kemudian dilakukan pengambilan darah setiap kelompok untuk mengetahui kadar glukosa darah puasa normal tikus. Setelah itu tikus diberikan infus D10 dan makanan, kemudian di ukur kadar gula darah 2 jam post prandial. selanjutnya disuntikkan diabetogen STZ dengan dosis $45 \mathrm{mg} / \mathrm{KgBB}$ secara intraperitoneal. Setela 3 hari pemaparan gula darah tikus diukur mengunakan alat gluco-dr, gula darah tikus yang lebih besar dari $180 \mathrm{mg} / \mathrm{dl}$ digunakan untuk perlakuan selanjutnya. Kemudain tikus yang gula darahnya $>180 \mathrm{mg} / \mathrm{dl}$ dibiarkan selama 2 miggu dengan akses minum dan makan secukupnya dan diberi suspensi fraksi air daun karamunting masing-masing kelompok 70 mg/KgBB, 140 mg/KgBB, dan $280 \mathrm{mg} / \mathrm{KgBB}$ dan diberi suspensi Na CMC $1 \%$ untuk kelompok kontrol negatif dan suspensi glibenclamide untuk kelompok kontrol positif. Pada hari ke 14 dilakukan pengukuran kadar gula darah menggunakan alat gluco-dr dan pengukuran kadar insulin dengan menggunakan metoda ELISA.

\section{HASIL}

Uji Fitokimia Fraksi Air Daun Karamunting (Rhodomyrtus tomentosa (Ait.) Hassk).

Uji Fitokimia dilakukan untuk mengetahui kandungan metabolit sekunder apa saja yang terkandung didalam fraksi air daun karamunting (Rhodomyrtus tomentosa (Ait.) Hassk). Uji ini dilakukan di 
Efektivitas Antidiabetes Fraksi Air Daun Karamunting (Rhodomyrtus Tomentosa (Ait.) Hassk.)... Geri Febriyanto, Mgs. Irsan Saleh, Theodorus

Laboratorium Biokimia dan Kimia Medik

Fakultas Kedokteran UNSRI dan pengujian

kadar insulin menggunakan metode ELISA.
Hasil Uji fitokimia dapat dilihat pada tabel berikut:

Tabel 1. Hasil Uji Fitokimia Fraksi Air Daun Karamunting (Rhodomyrtus tomentosa (Ait.) Hassk).

\begin{tabular}{cllc}
\hline No. & \multicolumn{1}{c}{ Jenis Uji } & \multicolumn{1}{c}{ Kejadian } & Hasil \\
\hline 1 & Alkaloid: Dragendorf & Endapan warna merah jingga & + \\
\hline & Alkaliod: Mayer & $\begin{array}{l}\text { Tidak ada endapan warna putih } \\
\text { kekuningan }\end{array}$ & + \\
\hline 2 & Flavonoid & Terbentuk warna merah & + \\
\hline 3 & Tritepenoid & Terbentuk cincin kecoklatan & + \\
\hline & Steroid & $\begin{array}{l}\text { Tidak terbentuk cinicn biru } \\
\text { kehijauan }\end{array}$ & + \\
\hline 4 & Saponin & $\begin{array}{l}\text { Terbentuk busa yang mantap dan } \\
\text { tinggi }\end{array}$ & + \\
\hline 5 & Tanin & Warna biru kehitaman & + \\
\hline 6 & Kuinon & Tidak terbentuk warna merah & + \\
\hline 7 & Wagner & Ada endapan jingga kecoklatan & \\
\hline & &
\end{tabular}

Berdasarkan Tabel 1, dapat dilihat bahwa fraksi air daun karamunting (Rhodomyrtus tomentosa (Ait.) Hassk) positif mengandung metabolit sekunder alkaloid, flavonoid, triterpenoid, saponin, dan tannin.

\section{Efektivitas Fraksi Air Daun Karamunting}

(Rhodomyrtus tomentosa (Ait.) Hassk).
Terhadap Kadar Glukosa Darah Sebelum dan Sesudah Perlakuan.

Hasil uji efektivitas fraksi air daun karamunting (Rhodomyrtus tomentosa (Ait.) Hassk). Terhadap kadar glukosa darah 2 jam PP sebelum dan sesudah perlakuan dilakukan analisis paired sample t-test. Hasil dapat dilihat pada Tabel 2.

Tabel 2. Efektivitas Fraksi Air Daun karamunting (Rhodomyrtus tomentosa (Ait.) Hassk). Terhadap kadar glukosa darah 2 jam PP sebelum dan sesudah perlakuan.

\begin{tabular}{llccc}
\hline Kelompok Subjek & $\mathbf{n}$ & $\begin{array}{c}\text { Sebelum }(\mathbf{m g} / \mathbf{d L}) \\
\text { Mean } \pm \text { SD }\end{array}$ & $\begin{array}{c}\text { Sesudah }(\mathbf{m g} / \mathbf{d L}) \\
\text { Mean } \pm \text { SD }\end{array}$ & $\boldsymbol{P}$ \\
\hline Glibenclamide & 6 & $305,83 \pm 7,33$ & $205,50 \pm 6,473$ & 0,001 \\
\hline Na CMC & 6 & $295,50 \pm 14,15$ & $303,00 \pm 22,821$ & 0,393 \\
\hline Fraksi 70mg/KgBB & 6 & $300,50 \pm 3,937$ & $241,17 \pm 10,944$ & 0,001 \\
\hline Fraksi & 6 & $292,33 \pm 6,470$ & $180,83 \pm 6,306$ & 0,001 \\
140mg/KgBB & & & & \\
\hline $\begin{array}{l}\text { Fraksi } \\
\text { 280mg/KgBB }\end{array}$ & 6 & $296,67 \pm 5,007$ & $144,33 \pm 7,00$ & 0,001 \\
\hline Paired samplettest $(p=0,05)$ & & & & \\
\hline
\end{tabular}

Paired sample t-test $(p=0,05)$

Uji efektifitas dilakukan menggunakan uji paired t-test. Uji ini bermakna apabila nilai $p<0.05$. Pada data kadar glukosa darah 2 jam PP sebelum dan sesudah perlakuan menunjukkan bahwa kelompok kontrol positif, kelompok fraksi $70 \mathrm{mg} / \mathrm{KgBB}$, $140 \mathrm{mg} / \mathrm{KgBB}$, dan $280 \mathrm{mg} / \mathrm{KgBB}$ efektif menurunkan kadar glukosa darah pada 
tikus secara signifikan. Hal ini sejalan dengan penilitian yang dilakukan oleh Sinata dan Helmi (2016) bahwa fraksi air daun karamunting (Rhodomyrtus tomentosa (Ait.) Hassk) dapat menurunkan kadar glukosa Darah secara signifikan pada mencit diabetes pada dosis 10, 20, dan 40 $\mathrm{mg} / \mathrm{KgBB}$.

Perbandingan Efektifitas Fraksi Air Daun Karamunting (Rhodomyrtus tomentosa (Ait.) Hassk). Terhadap Kadar Glukosa Darah 2 Jam PP Antar Kelompok Sesudah Perlakuan.

Tabel 3. Perbandingan Efektivitas Fraksi Air daun Karamunting (Rhodomyrtus tomentosa (Ait.) Hassk).

Antar kelompok terhadap kadar glukosa darah 2 jam PP sesudah perakuan.

\begin{tabular}{|c|c|c|c|c|c|}
\hline Kelompok & $\begin{array}{l}\text { Glibenclamide } \\
\text { Mean } \pm \text { SD: } \\
205,50 \pm 6,473\end{array}$ & $\begin{array}{l}\text { Na CMC } \\
\text { Mean } \pm \text { SD: } \\
303,00 \pm 22,821\end{array}$ & $\begin{array}{l}\text { Fraksi } \\
\text { 70mg/KgBB } \\
\text { Mean } \pm \text { SD: } \\
241,17 \pm 10,944\end{array}$ & $\begin{array}{l}\text { Fraksi } \\
140 \mathrm{mg} / \mathrm{KgBB} \\
\text { Mean } \pm \text { SD: } \\
180,83 \pm 6,306\end{array}$ & $\begin{array}{l}\text { Fraksi } \\
280 \mathrm{mg} / \mathrm{KgBB} \\
\text { Mean } \pm \text { SD: } \\
144,33 \pm 7,005 \\
\end{array}$ \\
\hline $\begin{array}{l}\text { Glibenclamide } \\
\text { Mean } \pm \text { SD: } 205,50 \\
\pm 6,473\end{array}$ & - & $P: 0,001$ & $P: 0,001$ & $P: 0,001$ & $P: 0,001$ \\
\hline $\begin{array}{l}\text { Na CMC } \\
\text { Mean } \pm \text { SD: } 303,00 \\
\pm 22,821\end{array}$ & $P: 0,001$ & - & $P: 0,001$ & $P: 0,001$ & $P: 0,001$ \\
\hline $\begin{array}{l}\text { Fraksi } 70 \mathrm{mg} / \mathrm{KgBB} \\
\text { Mean } \pm \text { SD: } \\
241,17 \pm 10,944\end{array}$ & $P: 0,001$ & $P: 0,001$ & - & $P: 0,001$ & $P: 0,001$ \\
\hline $\begin{array}{l}\text { Fraksi } \\
\text { 140mg/KgBB } \\
\text { Mean } \pm \text { SD: } 180,83 \\
\pm 6,306 \\
\end{array}$ & $P: 0,001$ & $P: 0,001$ & $P: 0,001$ & - & $P: 0,001$ \\
\hline $\begin{array}{l}\text { Fraksi } \\
\text { 280mg/KgBB } \\
\text { Mean } \pm \text { SD: } 144,33 \\
\pm 7,005\end{array}$ & $P: 0,001$ & $P: 0,001$ & $P: 0,001$ & $P: 0,001$ & - \\
\hline
\end{tabular}

Dari data diatas dapat disimpulkan bahwa fraksi air daun karamunting lebih efektif dibandingkan dengan glibenclamide dalam menurunkan kadar glukosa darah pada
Perbandingan efektivitas fraksi air daun karamunting (Rhodomyrtus tomentosa (Ait.) Hassk). Dilakukan antar kelompok terhadap kadar glukosa darah 2 jam PP sesudah perlakuan dimulai dari kelompok Glibenclamide, Na CMC, Fraksi 70mg/KgBB, Fraksi $140 \mathrm{mg} / \mathrm{KgBB}$, dan fraksi $280 \mathrm{mg} / \mathrm{KgBB}$. Data hasil perbandingan efektivitas fraksi air daun karamunting antar kelompok sesudah perlakuan dapat dilihat pada table 3. Analisa perbandingan efektivitas ini menggunakan metode analisis independent sample t-test. tikus diabetes terutama pada fraksi air daun karamunting dosis $280 \mathrm{mg} / \mathrm{KgBB}$.

Efektivitas Fraksi Air Daun Karamunting (Rhodomyrtus tomentosa (Ait.) Hassk). 
Efektivitas Antidiabetes Fraksi Air Daun Karamunting (Rhodomyrtus Tomentosa (Ait.) Hassk.)...

Geri Febriyanto, Mgs. Irsan Saleh, Theodorus

Terhadap Kadar Insulin Sebelum dan

tomentosa (Ait.) Hassk). Terhadap kadar Sesudah Perlakuan. insulin sebelum dan sesudah perlakuan

Hasil pengujian efektifitas fraksi air dianalisis menggunakan paired sampe $t$ daun karamunting (Rhodomyrtus test. Hasilnya dapat dilihat pada tebel 4.

Tabel 4. Efektivitas Fraksi Air Daun Karamunting (Rhodomyrtus tomentosa (Ait.) Hassk). Terhadap Kadar Insulin sebelum dan sesudah perlakuan.

\begin{tabular}{llccc}
\hline Kelompok Subjek & $\mathbf{n}$ & $\begin{array}{c}\text { Sebelum } \mathbf{( m g / d L}) \\
\text { Mean } \pm \text { SD }\end{array}$ & $\begin{array}{c}\text { Sesudah }(\mathbf{m g} / \mathbf{d L}) \\
\text { Mean } \pm \text { SD }\end{array}$ & $\boldsymbol{P}$ \\
\hline Glibenclamide & 6 & $33,33 \pm 1,211$ & $121,00 \pm 2,366$ & 0,001 \\
\hline Na CMC & 6 & $32,67 \pm 0,816$ & $33,00 \pm 1,265$ & 0,465 \\
\hline Fraksi 70mg/KgBB & 6 & $33,50 \pm 1,378$ & $87,00 \pm 1,414$ & 0,001 \\
\hline Fraksi & 6 & $33,83 \pm 1,472$ & $125,00 \pm 1,414$ & 0,001 \\
$\begin{array}{l}\text { 140mg/KgBB } \\
\text { Fraksi }\end{array}$ & 6 & $32,83 \pm 1,472$ & $135,00 \pm 0,894$ & 0,001 \\
280mg/KgBB & & & \\
\hline Paired sample t-test $(p=0,05)$ & & & &
\end{tabular}

Table diatas menunjukkan adanya

peningkatan secara signifikan kadar insulin pada kelompok kontrol positif, fraksi $70 \mathrm{mg} / \mathrm{Kgbb}$, fraksi $140 \mathrm{mg} / \mathrm{KgBB}$, dan $280 \mathrm{mg} / \mathrm{KgBB}$ sebelum dan sesudah perlakuan yang ditandai dengan nilai $\mathrm{P}=$ $0,001(<0,05)$. Sedangkan pada kelompok kontrol negatif nilai $p=0,465(>0,05)$ yang menunjukkan tidak adanya peningkatan secara signifikan kadar insulin pada kelompok kontrol negatif sebelum dan sesudah perlakuan.
Perbandingan Efektivitas Fraksi Air daun

Karamunting (Rhodomyrtus tomentosa

(Ait.)Hassk). Terhadap Kadar Insulin Antar Kelompok Sesudah Perlakuan.

Hasil pegujian perbangan efektivitas fraksi air daun karamunting terhadap kadar insulin antar kelompok sesudah perlakuan ditampilkan pada table 4.8. Analisa hasil perbandingan ini dilakukan menggunakan independent sample t-test.

Tabel 5. Perbandingan Efektivitas fraksi Air daun Karamunting terhadap Kadar Insulin Antar Kelompok

\begin{tabular}{|c|c|c|c|c|c|}
\hline Kelompok & $\begin{array}{l}\text { Glibenclamide } \\
\text { Mean } \pm \text { SD: } \\
121,00 \pm 2,366\end{array}$ & $\begin{array}{l}\text { Na CMC } \\
\text { Mean } \pm \text { SD: } \\
33,00 \pm \\
1,256\end{array}$ & $\begin{array}{l}\text { Fraksi } \\
\text { 70mg/KgBB } \\
\text { Mean } \pm \text { SD: } \\
87,00 \pm 1,414\end{array}$ & $\begin{array}{l}\text { Fraksi } \\
140 \mathrm{mg} / \text { KgBB } \\
\text { Mean } \pm \text { SD: } \\
125,00 \pm 1,414\end{array}$ & $\begin{array}{l}\text { Fraksi } \\
280 \mathrm{mg} / \mathrm{KgBB} \\
\text { Mean } \pm \text { SD: } \\
135,00 \pm 0,894\end{array}$ \\
\hline $\begin{array}{l}\text { Glibenclamide } \\
\text { Mean } \pm \text { SD: } 121,00 \\
\pm 2,366\end{array}$ & - & $P: 0,001$ & $P: 0,001$ & $P: 0,005$ & $P: 0,001$ \\
\hline $\begin{array}{l}\text { Na CMC } \\
\text { Mean } \pm \text { SD: } 33,00 \\
\pm 1,256\end{array}$ & $P: 0,001$ & - & $P: 0,001$ & $P: 0,001$ & $P: 0,001$ \\
\hline
\end{tabular}




\begin{tabular}{|c|c|c|c|c|c|}
\hline Kelompok & $\begin{array}{l}\text { Glibenclamide } \\
\text { Mean } \pm \text { SD: } \\
121,00 \pm 2,366\end{array}$ & $\begin{array}{l}\text { Na CMC } \\
\text { Mean } \pm \text { SD: } \\
33,00 \pm \\
1,256\end{array}$ & $\begin{array}{l}\text { Fraksi } \\
\text { 70mg/KgBB } \\
\text { Mean } \pm \text { SD: } \\
87,00 \pm 1,414\end{array}$ & $\begin{array}{l}\text { Fraksi } \\
\text { 140mg/KgBB } \\
\text { Mean } \pm \text { SD: } \\
125,00 \pm 1,414\end{array}$ & $\begin{array}{l}\text { Fraksi } \\
280 \mathrm{mg} / \mathrm{KgBB} \\
\text { Mean } \pm \text { SD: } \\
135,00 \pm 0,894\end{array}$ \\
\hline $\begin{array}{l}\text { Fraksi } 70 \mathrm{mg} / \mathrm{KgBB} \\
\text { Mean } \pm \text { SD: } \\
87,00 \pm 1,414\end{array}$ & $P: 0,001$ & $P: 0,001$ & - & $P: 0,001$ & $P: 0,001$ \\
\hline $\begin{array}{l}\text { Fraksi } \\
140 \mathrm{mg} / \mathrm{KgBB} \\
\text { Mean } \pm \text { SD: } 125,00 \\
\pm 1,414\end{array}$ & $P: 0,005$ & $P: 0,001$ & $P: 0,001$ & - & $P: 0,001$ \\
\hline $\begin{array}{l}\text { Fraksi } \\
280 \mathrm{mg} / \mathrm{KgBB} \\
\text { Mean } \pm \text { SD: } 135,00 \\
\pm 0,894\end{array}$ & $P: 0,001$ & $P: 0,001$ & $P: 0,001$ & $P: 0,001$ & - \\
\hline
\end{tabular}

Independent sample t-test $(\mathrm{p}=0,05)$

Data diatas menunjukkan bahwa fraksi air daun karamunting lebih efektif meningkatkan kadar insulin pada tikus

\section{PEMBAHASAN}

Hasil uji fitokimia pada Fraksi air daun karamunting yang ada pada Tabel 1 menunjukkan bahwa fraksi air daun karamunting mengandung senyawa metabolit sekunder alkaloid, flavonoid, triterpenoid, saponin, dan tannin. Hasil ini sejalan dengan hasil penelitian sebelumnya yang dilakukan oleh Sutomo, dkk, (2010) yang mengidentifikasi daun karamunting yang hasilnya menunjukkan adanya senyawa golongan alkaloid, tannin, aleuron, katekol, dan saponin.

Fraksi air daun karamunting efektif menurunkan kadar glukosa darah tikus putih jantan. Hasil penelitian Hasibuan (2015) menunjukkan bahwa ekstrak daun karamunting dapat menurunkan kadar gula diabetes dibandingkan dengan glibenclamide yang ditunjukkan dengan nilai $p<0,05$.

darah pada mencit diabetes secara signifikan pada dosis $50 \mathrm{mg} / \mathrm{KgBB}$, 100mg/KgBB, dan 200mg/KgBB (Hasibuan, 2015). Berdasarkan data pada Tabel 3 dan 5 menunjukkan bahwa peningkatan dosis Fraksi diiringi juga dengan penurunan kadar glukosa darah dan peningkatan kadar insulin yang signifikan. Hal ini disebabkan setiap peningkatan dosis, berarti kadar zat metabolit sekunder yang terkandung di dalam fraksi air daun karamunting juga meningkat, yang menyebabkan semakin signifikannya penuruan kadar glukosa darah dan meningkatnya kadar insulin tikus diabetes. Metode fraksinasi yang digunakan dalam penarikan senyawa metabolit sekunder yang terkandung di dalam daun karamunting ini dinilai lebih unggul daripada metode yang lain dikarenakan 
Efektivitas Antidiabetes Fraksi Air Daun Karamunting (Rhodomyrtus Tomentosa (Ait.) Hassk.)... Geri Febriyanto, Mgs. Irsan Saleh, Theodorus

pada fraksi air terdapat senyawa-senyawa metabolit sekunder yang lebih spesifik yakni yang bersifat polar seperti flavonoid, yang berdasarkan hasil penelitian mampu memberikan efek sebagai antidiabetes. Kadar metabolit sekunder yang terkandung didalam fraksi air daun karamunting mampu berperan dalam mengembalikan keseimbangan kadar glukosa darah dengan menurunkan kadar glukosa darah dan meningkatkan kadar insulin.

Pada sel $\beta$ pankreas, diduga penghambatan radikal bebas akibat Streptozotocin oleh senyawa aktif fraksi air daun karamunting mengakibatkan sekresi insulin tetap terjadi sehingga kadar insulin dalam penelitian ini cenderung meningkat. Selain itu, pada sel yang memiliki reseptor insulin, juga diduga bahwa penghambatan radikal bebas oleh senyawa aktif fraksi air daun karamunting menyebabkan komunikasi dalam sel untuk aktivasi dan sensitifitas reseptor insulin meningkat sehingga GLUT-4 dapat berfungsi mengangkut glukosa dari sirkulasi darah ke dalam sel dan kadar glukosa dalam darah menurun. Glukosa darah yang diangkut akan mengalami metabolisme di dalam sel menjadi cadangan energi berupa glikogen di sel hati dan otot (Tibrani,2009)

Senyawa aktif dari fraksi air daun karamunting (Rhodomyrtus tomentosa (Ait.) Hassk) berperan sebagai antioxidant yang dapat mencegah dan mengurangi radikal bebas yang ditimbulkan oleh streptozotocin. Penyuntikan streptozotocin pada tikus dapat menyebabkan disfungsi pada sel $\beta$ pankreas akibat adanya radikal bebas yang dapat menyebabkan berkurangnya sekresi insulin dari sel $\beta$ pankreas dan menurunnya sensitifitas reseptor insulin pada sel yang memiliki reseptor insulin sehingga terjadilah kondisi DM tipe 2. STZ mempengaruhi oksidasi glukosa dan menurunkan biosintesis dan sekresi insulin. STZ masuk ke sel- $\beta$ pankreas melalui transporter glukosa GLUT2 menyebabkan menurunnya ekspresi dari GLUT2. Hal ini mengakibatkan menurunnya sensitifitas reseptor insulin perifer sehingga berdampak pada meningkatnya resistensi insulin dan meningkatkan kadar glukosa darah (Firdaus et al, 2016). Pemberian fraksi air daun karamunting dapat menghambat dan mengurangi efek radikal bebas oleh streptozotocin sehingga sekresi insulin tetap terjadi dan meningkatkan sensitifitas reseptor insulin pada sel yang memiliki reseptor insulin. Akibatnya kadar glukosa darah menurun karena dapat diambil oleh sel tersebut untuk digunakan sebagai cadangan energi (Tibrani, 2009).

Flavonoid diketahui memiliki aktifitas antioksidan yang berkaitan dengan aktifitas antidiabetes. Flavonoid diketahui memiliki aktifitas antioksidan yang diyakini mampu 
melindungi tubuh terhadap kerusakan yang disebabkan spesies oksigen reaktif, sehingga mampu menghambat terjadinya penyakit degeneratif seperti DM. Terkait mekanisme penyembuhan penyakit diabetes, flavonoid diduga berperan secara signifikan meningkatkan aktivitas enzim antioksidan dan mampu meregenerasi selsel $\beta$ pankreas yang rusak sehingga defisiensi insulin dapat diatasi. Flavonoid yang terkandung di dalam tumbuhan diduga juga dapat memperbaiki sensitifitas reseptor insulin. Sehingga adanya flavonoid memberikan efek yang menguntungkan pada keadaan DM. Mekanisme lain dari flavonoid yang menunjukkan efek hipoglikemik yaitu mengurangi penyerapan glukosa dan mengatur aktivitas ekspresi enzim yang terlibat dalam metabolisme karbohidrat (Sasmita et al, 2017). Ada beberapa mekanisme kerja obat hipoglikemik oral, yaitu meningkatkan sekresi insulin (golongan sulfonilurea), meningkatkan kepekaan reseptor insulin sehingga absorpsi glukosa di jaringan perifer meningkat, meningkatkan kepekaan insulin jaringan otot, jaringan lemak dan hati, serta menghambat penguraian polisakarida menjadi monosakarida. Glibenclamide yang merupakan salah satu obat hipoglikemik oral golongan sulfonilurea menurunkan kadar glukosa darah dengan cara meningkatkan kadar insulin. Glibenclamide menyebabkan $\mathrm{K}^{+}$ channel tertutup sehingga ketika $\mathrm{K}+$ channel tertutup maka channel kalsium $\left(\mathrm{Ca}^{2+}\right)$ akan terbuka dan menyebabkan terjadinya depolarisasi sehingga insulin bisa disekresikan. Ketika insulin berhasil disekresikan maka insulin memberikan sinyal kepada transport glukosa GLUT4 secara transductional sehingga glukosa akan dibawa masuk ke dalam membrane sel oleh GLUT4 dan glukosa akan diproses menjadi ATP didalam membrane sel yang menyebabkan kadar glukosa darah menurun. Flavonoid mempunyai mekanisme sama dengan obat hipoglikemik oral golongan sulfonilurea dalam menurunkan kadar glukosa darah tikus dengan cara meningkatkan sekresi insulin pada organ pankreas (Sasmita et al, 2017). Flavonoid juga dapat menghambat fosfodiesterase sehingga meningkatkan CAMP pada sel beta pankreas. Peningkatan CAMP akan menstimulasi pengeluaran protein kinase $A$ (PKA) yang merangsang sekresi insulin semakin meningkat (Ajie, 2015).

Alkaloid dalam menurunkan kadar glukosa darah adalah dengan cara menghambat enzim $\alpha$-glukosidase pada mukosa duodenum sehingga penguraian polisakarida menjadi monosakarida dapat terhambat. Dengan demikian glukosa yang dilepaskan juga lebih lambat dan 
Efektivitas Antidiabetes Fraksi Air Daun Karamunting (Rhodomyrtus Tomentosa (Ait.) Hassk.)... Geri Febriyanto, Mgs. Irsan Saleh, Theodorus

absorbsinya ke dalam darah kurang cepat dan lebih rendah sehingga puncak kadar gula darah dapat dihindari (Sundhani et al, 2016).

Mekanisme terpenoid dalam menurunkan kadar glukosa darah yaitu dengan merangsang pengeluaran insulin dan membantu penyerapan glukosa dengan cara merangsang GLUT-4 di dalam sel (Sundhani et al, 2016)

Saponin bekerja dengan cara menghambat kerja enzim $\alpha$-glukosidase yaitu enzim yang ada di dalam usus yang berfungsi untuk mengubah karbohidrat menjadi glukosa. Enzim $\alpha$-glukosidase inhibitor ini menghambat absorpsi glukosa pada usus halus, sehingga berfungsi sebagai antihiperglikemi (penurun kadar glukosa darah). Pengaruh saponin terhadap susunan membran sel dapat menghambat absorbsi molekul dan menimbulkan gangguan pada sistem transporter glukosa sehingga akan terjadi hambatan untuk penyerapan glukosa (Fiana, 2016). Saponin juga merangsang pelepasan glucagon like peptide-1 (GLP-1) sehingga terjadinya aktivasi dan proliferasi sel $\alpha$ pada sel punca. Aktivasi tersebut akan meningkatkan regenerasi sel pankreas dengan penambahan jumlah sel $\alpha$ sehingga terjadi sekresi insulin yang adekuat dan glukosa darah terkontrol (Pandiangan, 2019). Selain saponin, tanin juga memiliki peranan dalam menurunkan kadar glukosa darah. Tanin bersifat atringen yang berkerja dalam membentuk lapisan dari protein selaput lendir yang melindungi usus sehingga dapat menghambat penyerapan glukosa (Fiana, 2016). Sedangkan Tanin mampu meningkatkan transpor glukosa dengan mengaktivasi insulin-mediated signaling pathway (Parawansah, 2015).

Penelitian ini menjelaskan bahwa fraksi air daun karamunting (Rhodomyrtus tomentosa (Ait.) Hassk) efektif menurunkan kadar glukosa darah dan meningkatkan kadar insulin pada tikus model diabetes. Dosis yang paling efektif adalah $280 \mathrm{mg} / \mathrm{KgBB}$. Hal ini dikarenakan pada dosis $280 \mathrm{mg} / \mathrm{KgBB}$ jumlah kandungan zat aktifnya cenderung lebih banyak sehingga memiliki efek yang lebih signifikan dibandingkan dengan dosis $70 \mathrm{mg} / \mathrm{KgBB}$ dan $140 \mathrm{mg} / \mathrm{KgBB}$.

\section{KESIMPULAN}

Berdasarkan hasil dan pembahasan diatas dapat disimpulkan bahwa fraksi air daun karamunting (Rhodomyrtus tomentosa (Ait.)Hassk) efektif menurunkan kadar glukosa darah 2 jam post prandial dan meningkatkan kadar insulin tikus putih jantan model diabetes dengan dosis $280 \mathrm{mg} / \mathrm{KgBB}$ yang merupakan dosis yang paling efektif. 


\section{DAFTAR PUSTAKA}

Ajie, Rizki B, 2015. White Dragon Fruit (Hylocereus undatus) Potentials as Diabetes Mellitus Treatment. J Majority. 4(1).

Banjarnahor E, 2012. Sel Beta Pankreas Sintesis dan Sekresi Insulin. Jurnal Biomedik. 4(3):156-162.

Decroli Eva, 2019. Diabetes Mellitus type 2. Pusat Penerbitan Bagian IImu Penyakit Dalam. Fakultas Kedokteran Universitas Andalas Padang.

Fiana N, Dwita O, 2016. Pengaruh Saponin Dalam Daging buah Makota Dewa (Phaleria macrocarpa) Terhadap Penurunan Kadar Glukosa Darah. Medical Journal of Lampung University. 5(4): 128-132.

Firdaus, Rimbawan, Marliyati SA, Rosita K, 2016. Model Tikus Diabetes Yang Diinduksi Streptozotocin-Sukrosa Untuk Pendekatan Penelitian Diabetes Mellitus Gestasional. Jurnal Media Kesehatan Masyarakat Indonesia. 12(1).

Geetha KM, Vinaykumar P, Vedigounder M, 2012. Hepatoprotective Activity of Aqueous Alcoholic (70\%) Extract of Rhodomyrtus tomentosa (Aiton.) Hssk.) Against Antitubercular Drugs Induced Hepatic Damage. Department of Pharmacology.
Hamid HA, Senait SZRM, Mashitah MY, 2017. Rhodomyrtus tomentosa: A Phytochemical

and

Pharmacological Review. Department of Chemistry. University Malaysia Pahang. Asian Journal of Pharmacological and Clinical Research Review, Vol.10. Gambang Kuantan, Pahang, Malaysia.

Hasibuan R, Syafruddin I, Saleha H, 2015. Effect of Leave Extract Haramonting (Rhodomyrtus tomentosa) to Lower Blood Sugar Level in Mice Induced Alloxan. International Journal of Pharmtech Research. 8 (6): 284-291.

International Diabetes Federation (IDF), 2017. Diabetes Atlas $8^{\text {th }}$ Edition, International Diabetes Federation (IDF).

Pandiangan A, Kristiani G, 2019. Pemberian Ekstrak Biji Jinten Hitam Pada Diabetes Mellitud Tipe 2 Sebagai Terapi. Jurnal Farmasetis. 8 (2):6774.

Parawansyah, Sufik G, Yusuf mi, 2015. Uji Efek Antidiabetik Ekstrak Daun Binahong (Cordyline fruticosa L.A cheval) Mus musculus yang Diinduksi Streptoztocin. 2 (2).

Riset Kesehatan Dasar (RISKESDAS). 2018. Kementerian Kesehatan RI. Badan 
Efektivitas Antidiabetes Fraksi Air Daun Karamunting (Rhodomyrtus Tomentosa (Ait.) Hassk.)... Geri Febriyanto, Mgs. Irsan Saleh, Theodorus

Penelitian dan Pengembangan

Kesehatan.

Saputra, Nengah T, I Nyoman S, Dharmayudha AAGO. 2018. Agen

Diabetagonik Streptozotocin

Untuk Membuat Tikus putih Jantan Diabetes Mellitus. Buletin Veteriner Udayana. 10 (2): 116121.

Sasmita Fw, Susetyarini E, Pantiwati Y, 2017. Efek Ekstrak Daun Kembang Bulan (Tithonia diversifolia) terhadap Kadar Glukosa Darah Tikus Wistar (Rattus Novergikus) yang Diinduksi Alloxan. Majalah Ilmiah Biologi Biosfera. 34(1): 22-31.

Shahab A, 2017. Dasar-Dasar Endokrinologi. Penerbit Rayyana Komunikasindo.

Sinata N, Helmi A, 2016. Antidiabetes dari Fraksi Air Daun Karamunting (Rhodomyrtus tomentosa (Ait.) Hssk.) Terhadap Kadar Glukosa Darah Mencit Diabetes. Jurnal Sains Farmasi \& Klinis. 3 (1):72-78. Sundhani E, Syarifah DCN, Zumrohani LR, Nurulita NA, 2016. Efektivitas Ekstrak Etanol Daun Adam Hawa (Rhoeo discolor) dan Daun Pucuk
Merah (Syzygium campanulatum Korth.) Dalam Menurunkan Kadar Gula Darah Pada Tikus Putih Jantan Galur Wistar Dengan Pembebanan Glukosa. Pharmacy. $13(2)$.

Sutomo A, Febri H, Yuwono M, 2010. Kajian Farmakognostik Simplisia Daun Karamunting (Rhosomyrtus tomentosa) Asal Pelaihari Kalimantan Selatan. Sains.

Szkudelski T, 2001. The Mechanism of Alloxan And Streptozotocin Action in B Cells of The Rat Pancreas. Department of Animal and Physiology and Biochemistry, University of Agriculture, Poznan, Poland. Physiol. Res. 50: 536-546, 2001

Tibrani M, 2009. Kadar Insulin Plasma Mencit Yang Dikondisikan Diabetes Mellitus Setelah Pemberian Ekstrak Air Daun Nimba. Universitas Sriwijaya.

WHO, 2012. Diabetes Fact Sheet. Department of Sustainable Development and Healthy Environment. 